\title{
Prevalence of congenital anomalies in babies and associated maternal etiological factors at tertiary care hospital
}

\author{
Shahana I. Chandniwala* \\ Department of Obstetrics and Gynecology, B. J. Medical College and Civil Hospital, Ahmedabad, Gujarat, India
}

Received: 19 August 2021

Revised: 30 September 2021

Accepted: 01 October 2021

\section{*Correspondence:}

Dr. Shahana I. Chandniwala,

E-mail: shahanachandniwala@gmail.com

Copyright: $\odot$ the author(s), publisher and licensee Medip Academy. This is an open-access article distributed under the terms of the Creative Commons Attribution Non-Commercial License, which permits unrestricted non-commercial use, distribution, and reproduction in any medium, provided the original work is properly cited.

\section{ABSTRACT}

Background: The objective of this study was to know the local prevalence of congenital anomaly and study the maternal risk factors associated with it.

Methods: Cross sectional descriptive study was carved out. All live babies were examined for presence of congenital anomalies and mother were looked for presence of socio-demographic factor.

Results: In this study of 1 year 5767 live birth took place at tertiary care centre out of which 63 babies had congenital anomalies. Therefore, prevalence of congenital anomalies at tertiary care centre was $1.08 \%$.

Conclusions: The incidence of malformations were significantly higher in babies born to mothers over the age of 35 years and with parity 4 and above.

Keywords: Congenital anomalies, Consanguinity, Teratogens

\section{INTRODUCTION}

Study of birth defect and their etiology is termed as teratology, the term was borrowed in 1842 from French teratologie, where it was formed in 1830 from Greek Tepac teras, meaning "sign sent by gods, portent, marvel, monster". ${ }^{1}$ A teratogen may be defined as any agent that act during embryonic or fetal development to produce permanent alteration of form or function. ${ }^{2}$ Thus, a teratogen may be a medication or other chemical substance, a physical or environmental factor such as heat or radiation, a maternal metabolites as in diabetes or phenylketonuria, or an infection such as cytomegalovirus. Even obesity is considered as a teratogen.

\section{Causes and risk factors ${ }^{3,4}$}

Genetic factors: many congenital anomalies results either from mutation of genes or inheritance of genes that codes for anomaly. Consanguinity increase the prevalence of rare genetic defects.
Socioeconomic and demographic factors: In lower socioeconomic class there is lack of access to sufficient nutritious food for pregnant women, an increased exposure to infection and poorer access to healthcare and screening.

Maternal age is also a risk factor for abnormal intrauterine development of fetus.

Environmental factors: Maternal exposure to certain pesticides and other chemical, as well as certain medications, alcohol, tobacco and radiation during pregnancy. ${ }^{5-9}$

Infections: Syphilis, rubella, cytomegalovirus, toxoplasma and other infections.

Maternal nutritional status: Folate deficiency increases the risk of having baby with neural tube defects while excessive intake of vitamin-A may affect the development of embryo or fetus. 


\section{METHODS}

This was a cross sectional study conducted at Civil Hospital Ahmedabad and B. J. Medical College in Gujarat. Babies born during the period of July 2019 to June 2020 were taken into study.

All the mothers were interrogated within 48 hours of delivery as per the proforma prepared. The proforma contained the particulars like maternal age, consanguinity, education, socioeconomic status, and antenatal history in detail with reference to drug intake, fever, and exposure to irradiation. Medical diseases complicating pregnancy like diabetes, heart disease, and hypertension were also taken into account. A detailed obstetric history with reference to previous abortions and stillbirths were taken from the mother.

A comprehensive family history of any member in the family having similar or any other anomaly was considered. Reproductive history especially about infertility, miscarriages, and stillbirth were inquired.

A complete physical examination of all new born including assessment of patient's anatomy for features varying from usual or normal standards was performed.

\section{RESULTS}

A total of 6067 deliveries took place in a period of one year from July 2019 to June 2020 at obstetrics and gynaecology department of tertiary care hospital in Gujarat. The number of live-births was 5765 and the number of stillbirths was 302. The prevalence of congenital malformation was 10 per 1000 birth (63 cases).

Table 1: Sex distribution and congenital malformations.

\begin{tabular}{|lllll|}
\hline Sex & $\begin{array}{l}\text { Normal } \\
\text { babies }\end{array}$ & $\begin{array}{l}\text { No. of } \\
\text { malformed } \\
\text { babies }\end{array}$ & $\begin{array}{l}\text { \% of } \\
\text { malformed } \\
\text { babies }\end{array}$ & $\begin{array}{l}\text { Total } \\
\text { babies }\end{array}$ \\
\hline Male & 2967 & 34 & 1.13 & 3001 \\
\hline Female & 2736 & 26 & 0.94 & 2764 \\
\hline *p value $=0.001$ & & & \\
\hline
\end{tabular}

Among the malformed babies 34 were male and 26 were female. 3 babies had ambiguous genitalia.

The chi-square value for these data was computed to be 9.89 and $\mathrm{p}$ value 0.001 , which was statistically significant. The odds ratio was 1.2 which shows that males have 1.2 times more risk compared to females.

Mothers were classified according to their age into four groups. The prevalence of malformed babies was found to be highest in the age group above 35 years, which is $6.98 \%$. Statistical analysis of the data by Chi- square trend shows that the risk of malformations increases with age, greatest risk suggested for the above-35 age group. The
Chi-square trend value for the data was computed to be 52.58 , and the $\mathrm{p}$ value was computed to be $<0.00001$, which is statistically significant (Table 2).

Table 2: Distribution of malformations according to the maternal age.

\begin{tabular}{|lllll|}
\hline $\begin{array}{l}\text { Mother's } \\
\text { age }\end{array}$ & $\begin{array}{l}\text { Normal } \\
\text { babies }\end{array}$ & $\begin{array}{l}\text { No. of } \\
\text { malformed } \\
\text { babies }\end{array}$ & $\begin{array}{l}\text { \% of } \\
\text { malformed } \\
\text { babies }\end{array}$ & $\begin{array}{l}\text { Odds } \\
\text { ratio }\end{array}$ \\
\hline $\mathbf{2 0}$ & 520 & 3 & 0.24 & 0.49 \\
\hline $\mathbf{2 0 - 3 0}$ & 4337 & 37 & 3.55 & 0.44 \\
\hline $\mathbf{3 0 - 3 5}$ & 732 & 14 & 2.84 & 1.90 \\
\hline$>\mathbf{3 5}$ & 113 & 9 & 6.98 & 7.9 \\
\hline
\end{tabular}

$* \mathrm{p}$ value $<0.00001$

\section{Consanguinity and congenital malformations}

$90.4 \%$ of babies with congenital malformations were born of non-consanguineous marriage as compared to $9.6 \%$ in the consanguineous group. As consanguineous marriage was not common in the group of population included in this study, the proportion of malformation due to consanguineous marriage was less. But, if we consider the prevalence of anomalies in the babies among couples with consanguineous marriage, it is high.

Table 3: Distribution of cases according to parity.

\begin{tabular}{|lllll|}
\hline Parity & $\begin{array}{l}\text { Normal } \\
\text { babies }\end{array}$ & $\begin{array}{l}\text { No. of } \\
\text { malformed } \\
\text { babies }\end{array}$ & $\begin{array}{l}\text { \% of } \\
\text { malformed } \\
\text { babies }\end{array}$ & $\begin{array}{l}\text { Odds } \\
\text { ratio }\end{array}$ \\
\hline Primi & 2447 & 26 & 1.06 & 0.93 \\
\hline $\mathbf{1}$ or $\mathbf{2}$ & 2028 & 18 & 0.8 & 0.72 \\
\hline $\mathbf{3}$ & 980 & 8 & 0.8 & 0.70 \\
\hline $\mathbf{Z}$ 4 & 247 & 11 & 4.4 & 4.67 \\
\hline *p value $<0.00011$ & & & \\
\hline
\end{tabular}

According to the parity, mothers were classified into four groups. It was observed that after the first child, there was an increase in incidence of congenital malformations among mothers with parity four and above. The Chisquare trend values for this set of data were 25.62, and the $\mathrm{p}$ value was 0.00011 . This observation suggest that there was a significant correlation between the parity and incidence of congenital malformations.

Out of 63 malformed babies, only $7.94 \%$ had history of drug intake during antenatal period and $3.17 \%$ of malformed cases had fever or infection, 1 patient had achondroplasia, which is autosomal dominant disorder, 2 patient had overt diabetes mellitus (Table 4).

From the observed data, the incidence of congenital malformations was observed to be more when the birth weight was less than $1.5 \mathrm{~kg}$. The chi-square trend value was computed as 5.09 with $\mathrm{p}$ value was found as 0.02 which was statistically significant. Hence weight $<1.5 \mathrm{~kg}$ 
was a significant risk factor for congenital malformations (Table 5).

Table 4: Correlation of antenatal factors with congenital malformations.

\begin{tabular}{|lll|}
\hline $\begin{array}{l}\text { Types of antenatal risk } \\
\text { factors }\end{array}$ & $\begin{array}{l}\text { No. of } \\
\text { malformed } \\
\text { babies }\end{array}$ & $\begin{array}{l}\text { \% of total } \\
\text { malformed } \\
\text { babies }\end{array}$ \\
\hline Nil & 45 & 71.43 \\
\hline $\begin{array}{l}\text { History of teratogenic } \\
\text { drugs ingestion }\end{array}$ & 5 & 7.94 \\
\hline History of fever/infection & 2 & 3.17 \\
\hline $\begin{array}{l}\text { History of infertility } \\
\text { treatment }\end{array}$ & 4 & 6.35 \\
\hline $\begin{array}{l}\text { Genetic disease (either } \\
\text { parents) }\end{array}$ & 1 & 1.59 \\
\hline Malformation in sibling & 4 & 6.35 \\
\hline $\begin{array}{l}\text { Known cases of diabetes } \\
\text { mellitus }\end{array}$ & 2 & 3.17 \\
\hline
\end{tabular}

Table 5: Birth weight and malformations.

\begin{tabular}{|lllll|}
\hline $\begin{array}{l}\text { Birth } \\
\text { weight } \\
\text { (kg) }\end{array}$ & $\begin{array}{l}\text { Normal } \\
\text { babies }\end{array}$ & $\begin{array}{l}\text { No. of } \\
\text { malformed } \\
\text { babies }\end{array}$ & $\begin{array}{l}\text { \% of total } \\
\text { malformed } \\
\text { babies }\end{array}$ & $\begin{array}{l}\text { Odds } \\
\text { ratio }\end{array}$ \\
\hline $\mathbf{2 . 5 - 3 . 5}$ & 3864 & 34 & 0.87 & 0.55 \\
\hline$<\mathbf{1}$ & 14 & 0 & 0 & 0 \\
\hline $\mathbf{1 - 1 . 5}$ & 103 & 6 & 5.5 & 5.77 \\
\hline $\mathbf{1 . 5 - 2 . 5}$ & 1362 & 24 & 1.73 & 1.96 \\
\hline $\mathbf{> 3 . 5}$ & 363 & 1 & 0.27 & 0.24 \\
\hline *p value $=0.02$ & & & \\
\hline
\end{tabular}

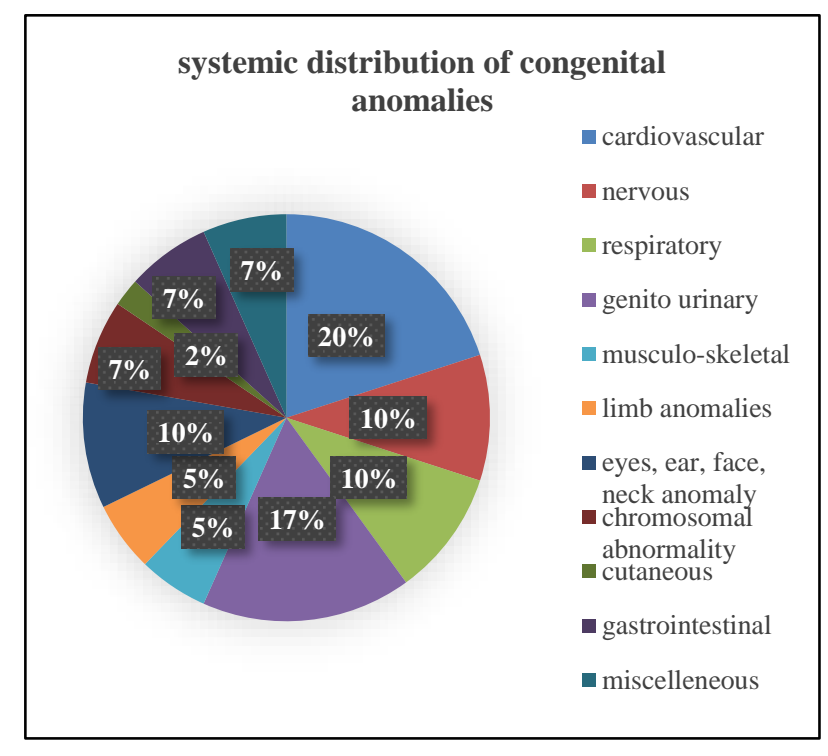

Figure 1: Systemic distribution and percentage of congenital anomalies.

\section{DISCUSSION}

Among 6067 births during the study period, 5765 were live births and 302 were stillbirths. The prevalence of congenital malformations in the present study was $1.08 \%$ (63 cases). Of these $73 \%$ (46 babies) had major anomalies and $27 \%$ (17 babies) had minor anomalies.

Table 6: Distribution of anomalies and prevalence in various studies.

\begin{tabular}{|c|c|c|c|}
\hline & $\begin{array}{l}\text { Present } \\
\text { study }\end{array}$ & $\begin{array}{l}\text { Datta } \\
\text { et } \text { al }^{10}\end{array}$ & $\begin{array}{l}\text { Patel et } \\
\mathrm{al}^{16}\end{array}$ \\
\hline Total live birth & 5765 & 2869 & 17325 \\
\hline $\begin{array}{l}\text { Prevalence of } \\
\text { anomalies }\end{array}$ & $63(1.08 \%)$ & $48(1.6 \%)$ & $179(1.8 \%)$ \\
\hline $\begin{array}{l}\text { Major } \\
\text { anomalies }\end{array}$ & 46 & 34 & 138 \\
\hline $\begin{array}{l}\text { Minor } \\
\text { anomalies }\end{array}$ & 17 & 11 & 41 \\
\hline
\end{tabular}

\section{Sex distribution}

Among the malformed babies 34 were male and 26 were female. Male:female ratio was 1:3 and it was statistically significant.

In a study conducted by Datta et al and Verma et al, no difference was observed in the distribution of malformations between the two sexes..$^{9,11}$

\section{Consanguinity and congenital malformation}

$91 \%$ of babies with congenital malformations were born of non-consanguineous marriage as compared to $9 \%$ in the consanguineous group. In the present study, congenital malformations like ventricular septal defect, critical aortic stenosis, patent ductus arteriosus and undescended testes were found to have higher incidence among consanguineous marriages.

But, cardiac defect, cleft lip and palate, syndactyly and polydactyly also seen in non-consanguineous group. Thus, we infer that these disorders may be due to polygenic or multifactorial inheritance.

\section{Maternal age and parity}

In this study the incidence of malformed babies was found to be significantly higher in the age group above 35 years, which was $6.98 \%$. Regarding maternal age and malformations, study conducted by Patel et al, the incidence of congenital malformations was higher in mothers >35 years of age. ${ }^{16}$ This clearly shows that increased maternal age is a definite risk factor for congenital malformations (Table 7).

In this study the incidence of malformed babies in mothers above parity 4 was $4.4 \%$. Typically, maternal age can be a risk factor for parities of 4 and above comparable to study Choudry et al. ${ }^{15}$ The average maternal age of the group with parity of 4 and above was found to be less than 30 . Therefore, the inference was that the risk of congenital 
malformation increases with the parity, regardless of maternal age.

Table 7: Prevalence of malformation in various studied according to maternal age.

\begin{tabular}{|lllllll|}
\hline $\begin{array}{l}\text { Mother's } \\
\text { age }\end{array}$ & $\begin{array}{l}\text { Present Study } \\
\text { Normal } \\
\text { babies }\end{array}$ & $\begin{array}{l}\text { Malformed } \\
\text { babies }\end{array}$ & $\begin{array}{l}\text { Datta et al } \\
\text { Normal } \\
\text { babies }\end{array}$ & $\begin{array}{l}\text { Malformed } \\
\text { babies }\end{array}$ & $\begin{array}{l}\text { Patel et al }^{10} \\
\text { Normal } \\
\text { babies }\end{array}$ & $\begin{array}{l}\text { Malformed } \\
\text { babies }\end{array}$ \\
\hline$<\mathbf{2 0}$ & 520 & $3(0.24 \%)$ & 261 & $3(1.1 \%)$ & 561 & $2(0.35 \%)$ \\
\hline $\mathbf{2 0 - 3 0}$ & 4337 & $37(3.5 \%)$ & 1967 & $27(1.3 \%)$ & 6132 & $130(2.1 \%)$ \\
\hline $\mathbf{3 0 - 3 5}$ & 732 & $14(2.8 \%)$ & 632 & $6(0.95 \%)$ & 2215 & $32(1.44 \%)$ \\
\hline$>\mathbf{3 5}$ & 113 & $9(6.9 \%)$ & 96 & $1(1.04 \%)$ & 416 & $14(3.6 \%)$ \\
\hline
\end{tabular}

Table 8: Prevalence of malformation in various studied according to parity.

\begin{tabular}{|lllll|}
\hline & Present study & & Patel Z.M. et. al ${ }^{16}$ & \\
\hline Parity & Normal babies & Malformed babies & Normal babies & Malformed babies \\
\hline Primi & 2447 & $26(1.06 \%)$ & 3321 & $62(1.86 \%)$ \\
\hline $\mathbf{1 - 2}$ & 2028 & $18(0.8 \%)$ & 3145 & $54(1.7 \%)$ \\
\hline $\mathbf{3}$ & 980 & $8(0.8 \%)$ & 2023 & $49(2.4 \%)$ \\
\hline$\geq \mathbf{4}$ & 247 & $11(4.4 \%)$ & 235 & $14(3.6 \%)$ \\
\hline
\end{tabular}

\section{Correlation of antenatal factors with congenital malformations ${ }^{6,7}$}

In this study, $7.94 \%$ of mothers with the malformed babies gave history of drug intake which is confirmatory with other studies. $^{5-7} 3.17 \%$ of malformed cases had fever or infection, 1 patient had achondroplasia, which is autosomal dominant disorder, 2 patient had overt diabetes mellitus in them deformity like ileocaecal atresia, ventricular septal defect, multicystic dysplastic kidney and skeletal deformities were noted in babies. 3 patient had history of severe anemia in $1^{\text {st }}$ trimester in those patients anomalies like spina-bifida, meningo-myelocele, Pierrie Robins syndrome and dysmorphic facial features were noted in babies. 5 patients conceived after treatment of infertility mainly after ovulation induction anomalies like scoliosis, duodenal atresia, VSD, congenital heart diseases like tetralogy of Fallot and double outlet right ventricle were noted.

Analysis of drug intake in the implication of congenital malformation revealed 1 patient had history of antiepileptic drug ingestion (valproate and topiramate), baby had radial aplasia, club hand and congenital diaphragmatic hernia. 2 patient had history of antithyroid (carbimazole) drug ingestion, deformity like aplasia cutis, tetralogy of Fallot, congenital diaphragmatic hernia, hydronephrosis and hydroureter are seen. 1 patient had history of MTP pills ingestion (mifepristone and misoprostol) during $1^{\text {st }}$ trimester, but eventually continued pregnancy, baby had deformity in ventricles of brain and mega cisterna magna.

On evaluation of maternal medical/gynaecological illness, 27 people had no illness during antenatal period and $38 \mathrm{had}$ illness. Out of 36 mothers, 2 had PIH, 1 had placenta previa, 1 had prolapse, 2 had diabetes mellitus. One case of achondroplasia was reported. The common anomalies associated with PIH were CNS and genital anomalies.

In this study 10 patients (15.87\%) of mother had polyhydramnios who gave birth to malformed babies. Malformations noted were duodenal atresia, jejunal atresia, tracho-oesophageal fistula, severe tracheal stenosis, congenital diaphragmatic hernia and tetralogy of Fallot. 5 patient had oligohydramnios, among these babies one had classical Potter-hydramnios sequence and one had $\mathrm{B} / \mathrm{L}$ pulmonary hypoplasia associated with multicystic dyasplastic kidneys.

Table 9: Systemic distribution of anomalies in various studies. $^{10,12}$

\begin{tabular}{|c|c|c|}
\hline \multirow[t]{2}{*}{$\begin{array}{l}\text { System } \\
\text { involved }\end{array}$} & \multicolumn{2}{|c|}{$\begin{array}{l}\text { Number of birth with } \\
\text { corresponding malformations } \\
(\%)\end{array}$} \\
\hline & Present study & Datta et al ${ }^{10}$ \\
\hline Cardiovascular & $18(28.57)$ & $2(4.1 \%)$ \\
\hline Nervous & $9(14.29)$ & $5(10.4 \%)$ \\
\hline Respiratory & $9(14.29)$ & 0 \\
\hline Genito-urinary & $15(23.81)$ & $3(6.2 \%)$ \\
\hline Musculo-skeletal & $5(7.94)$ & $3(6.2 \%)$ \\
\hline $\begin{array}{l}\text { Anomalies of } \\
\text { limb }\end{array}$ & $5(7.94)$ & $6(12.5 \%)$ \\
\hline $\begin{array}{l}\text { Eyes, ear, face, } \\
\text { neck anomaly }\end{array}$ & $9(14.29)$ & $7(14.5 \%)$ \\
\hline $\begin{array}{l}\text { Chromosomal } \\
\text { abnormality }\end{array}$ & $6(9.52)$ & $2(4.1 \%)$ \\
\hline Cutaneous & $2(3.17)$ & $1(2.0 \%)$ \\
\hline Gastrointestinal & $6(9.52)$ & $5(10.4 \%)$ \\
\hline Miscellaneous & $6(9.52)$ & $14(29.1 \%)$ \\
\hline
\end{tabular}


The commonest system involved in the present study was the cardiovascular system. The next common systems in our study were genitourinary followed by CNS and GIT which is in confirmatory with other study. ${ }^{13,14}$

\section{CONCLUSION}

The incidence of malformations were significantly higher in babies born to mothers over the age of 35 years and with parity 4 and above. Majority of malformations had no significant antenatal risk factors like fever, drug intake, etc. Hence for the prevention of anomalies, antenatal patients with age $>30$ years, higher parity and with risk factors need to be counselled regarding screening of anomalies.

Funding: No funding sources Conflict of interest: None declared

Ethical approval: The study was approved by the Institutional Ethics Committee

\section{REFERENCES}

1. Jacobson J. Teratogen update: polychlorinated biphenyls. Teratology. 1997;5(55):338-47.

2. Birth Defects. Howmed.net. 24 July 2011. Available from: http://howmed.net/anatomy/embryology/birthdefects/. Accessed on 1 November 2019.

3. Wilson JG. Environment and birth defects. Academic Press; 1973.

4. McHugh RK, Wigderson S, Greenfield SF. Epidemiology of substance use in reproductive-age women. Obstet Gynecol Clin North Am. 2014;41(2):177-89.

5. Bromley R, Weston J, Adab N, Greenhalgh J, Sanniti A, McKay AJ, et al. Treatment for epilepsy in pregnancy: neurodevelopmental outcomes in the child. Cochrane Database Syst Rev. 2014(10).

6. Barr Jr M, Cohen MM. ACE inhibitor fetopathy and hypocalvaria: the kidney-skull connection. Teratology. 1991;44(5):485-95.
7. Weiss CF, Glarko AJ, Weston JK. Chloramphenicol in the newborn Infant :a physiologic explanation of its toxicity when given in excessive doses. $\mathrm{N}$ Engl J Med. 1960;262:787.

8. Hoyme HE, Kalberg WO, Elliott AJ, Blankenship J, Buckley D, Marais AS, Manning MA, Robinson LK, Adam MP, Abdul-Rahman O, Jewett T. Updated clinical guidelines for diagnosing fetal alcohol spectrum disorders. Pediatrics. 2016;138(2).

9. Sullivan PM, Dervan LA, Reiger S, Buddhe S, Schwartz SM. Risk of congenital heart defects in the offspring of smoking mothers: a population-based study. J Pediatr. 2015;166(4):978-84.

10. Vikram D, Pushpa C. Congenital malformations in rural Maharashtra. Indian Pediatr. 2000;37(9):9981001.

11. Chaturvedi P, Banerjee KS. Spectrum of congenital malformation in newborns from rural Maharastra. Indian J Pediatr. 1989;56:501-7.

12. Verma M, Chnetwal JM, Singh D. Congenital malformation- retrospective study of 10,000 cases. Indian J Paediatr. 1991;58:245-52.

13. Mathur BC, Karan S, Vijayadevi KKL. Congenital malformations in newborns. Indian Pediatr. 1975;12:179-83.

14. Kalra A, Kalra K, Sharma V, Singh M, Dayal RS. Congenital malformations. Indian Pediatr. 1984;24:945-50.

15. Choudry AR, Mukherjee M, Sharma A, Talukdar G, Ghosh PK. Study of 1,26,266 consecutive births for major congenital defects. Indian $\mathrm{J}$ Pediatr. 1989;56:493-9.

16. Patel ZM, Adhia RA, Birth defects surveillance study. Indian J Pediatr. 2005;72:489-91.

Cite this article as: Chandniwala SI. Prevalence of congenital anomalies in babies and associated maternal etiological factors at tertiary care hospital. Int J Reprod Contracept Obstet Gynecol 2021;10:4189-93. 